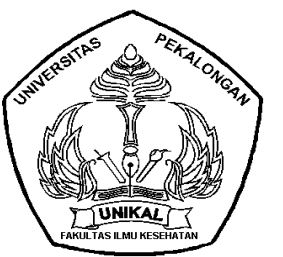

JURNAL KESEHATAN PENA MEDIKA VOL 11 (1) JUNI 2021

PENA MEDIKA

FAKULTAS ILMU KESEHATAN UNIVERSITAS PEKALONGAN

http://jurnal.unikal.ac.id/index.php/medika ISSN : 2086-843X

\title{
Upaya Peningkatan Pengetahuan Pencegahan Covid-19 Dengan Menggunakan Leaflet Pada Pasien Rawat Jalan Di UPTD Puskesmas Pare Kabupaten Kediri 2021
}

\author{
Vivien Dwi Purnamasari. ${ }^{1)}$, Fazal Efendi ${ }^{2)}$ \\ ${ }^{1,2)}$ Kesehatan Masyarakat, Institut Ilmu Kesehatan Bhakti Wiyata Kediri,

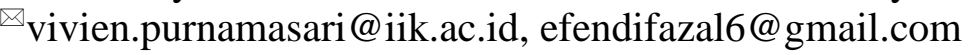

$\begin{array}{ll}\text { ARTICLE INFO } \\ \text { Accepted } & : 21 \text { Mei } 2021 \\ \text { Approve } & : \text { 02 Juni } 2021 \\ \text { Publish } & : \text { 30 Juni } 2021\end{array}$

\begin{abstract}
Coronavirus Disease 2019 (COVID-19) is an infectious disease caused by Severe Acute Respiratory Syndrome Coronavirus 2 (SARS-CoV-2). SARS CoV-2 is a new type of coronavirus that has never been identified in humans. There are at least two types of coronavirus that are known to cause diseases that can cause severe symptoms, such as Middle East Respiratory Syndrome (MERS) and Severe Acute Respiratory Syndrome (SARS). As a result of the spread of Covid-19, it causes impacts such as there are many fields of work that are laid off, changes in people's behavior, especially in the health sector, to the economic impact. Knowledge about the Covid-19 disease is very important so as not to cause an increase in the number of Covid-19 cases. Knowledge of Covid-19 patients can be interpreted as the result of knowing from patients about the disease, understanding the disease, how to prevent it, treat it and its complications. This study uses a quasi-experimental design with one group pre-test and post-test designs. The instruments in this study were questionnaires and leaflets. The questionnaire was given using a Google form link to outpatients at the UPTD Pare Health Center, Kediri Regency, which included knowledge about Covid-19 prevention and contained 10 questions. Based on the 20 respondents, most of the respondents were in the criteria of late adolescence 17-25 years as many as 8 people (40\%), female sex as many as 17 people (85\%), high school education as many as 10 people (50\%). during the pre-test with sufficient category as many as 10 respondents (45\%), while at the post-test with good category as many as 8 people (40\%). There is an increase in respondents' knowledge about preventing the transmission of Covid-19.
\end{abstract}

Keywords: Covid-19, Knowledge, Public Health Center

\begin{abstract}
Abstrak
Coronavirus Disease 2019 ( COVID- 19) merupakan penyakit menular yang diakibatkan oleh Severe Acute Respiratory Syndrome Coronavirus 2 (SARS- CoV- 2). SARS CoV- 2 ialah coronavirus tipe baru yang belum pernah diidentifikasi tadinya pada manusia. Terdapat setidaknya dua tipe coronavirus yang dikenal menimbulkan penyakit yang bisa memunculkan gejala berat semacam Middle East Respiratory Syndrome (MERS) serta
\end{abstract}


Severe Acute Respiratory Syndrome( SARS). Akibat penyebaran Covid-19 menyebabkan dampak seperti ada bidang pekerjaan yang banyak dilakukan PHK, perubahan perilaku masyarakat terutama dalam bidang kesehatan, hingga pada dampak ekonomi. Pengetahuan tentang penyakit Covid-19 merupakan hal yang sangat penting agar tidak menimbulkan peningkatan jumlah kasus penyakit Covid-19. Pengetahuan pasien Covid-19 dapat diartikan sebagai hasil tahu dari pasien mengenai penyakit, memahami penyakit, cara pencegahan, pengobatan dan komplikasinya. Penelitian ini menggunakan desain quasi experiment dengan rancangan one group pre test dan post test. Instrumen pada penelitian ini adalah kuesioner dan leaflet. Kuesioner diberikan dengan menggunakan link Google form kepada pasien rawat jalan UPTD Puskesmas Pare Kabupaten Kediri meliputi pengetahuan tentang pencegahan Covid-19 berisi 10 pertanyaan. Berdasarkan 20 responden responden sebagian besar pada kriteria masa remaja akhir 17-25 tahun sebanyak 8 orang (40\%), berjenis kelamin perempuan sebanyak 17 orang (85\%), pendidikan SMA sebanyak 10 orang (50\%), Sebagian besar tingkat pengetahuan responden pada saat pre test dengan kategori cukup sebanyak 10 responden (45\%), sedangkan pada saat post test dengan kategori baik sebanyak 8 orang $(40 \%)$. Terdapat peningkatan pengetahuan responden tentang pencegahan penularan Covid-19.

Kata kunci: Covid-19, Pengetahuan, Puskesmas

\section{PENDAHULUAN}

\section{Coronavirus Disease 2019}

COVID- 19) merupakan penyakit menular yang diakibatkan oleh Severe Acute Respiratory Syndrome Coronavirus 2 (SARS- CoV- 2). SARS CoV- 2 ialah coronavirus tipe baru yang belum pernah diidentifikasi tadinya pada manusia. Terdapat setidaknya dua tipe coronavirus yang dikenal menimbulkan penyakit yang bisa memunculkan gejala berat semacam

Middle East Respiratory Syndrome (MERS) serta Severe Acute Respiratory Syndrome( SARS). Ciri serta gejala umum infeksi COVID- 19 antara lain indikasi gangguan respirasi akut semacam demam, batuk serta sesak napas. Masa inkubasi rata- rata 5- 6 hari dengan masa inkubasi terpanjang 14 hari. Pada permasalahan COVID- 19 yang berat bisa menimbulkan pneumonia, sindrom pernapasan akut, gagal ginjal, serta bahkan kematian (Kementerian Kesehatan RI, 2020).

Penyakit coronavirus 2019 (COVID19) merupakan infeksi saluran pernapasan yang diakibatkan oleh coronavirus yang baru timbul yang awal dikenali muncul di Wuhan, Cina, pada bulan Desember 2019. Pengurutan genetika virus ini mengindikasikan kalau virus ini berjenis betacoronavirus yang terpaut erat dengan virus SARS. Walaupun sebagian besar orang yang terkena COVID- 19 hanya 
hadapi penyakit yang ringan ataupun tanpa komplikasi, sekitar $14 \%$ menderita penyakit parah yang membutuhkan perawatan rumah sakit serta dukungan oksigen, serta $5 \%$ butuh dimasukkan ke unit perawatan intensif (Word Health Organization, 2020).

Permasalahan virus Corona( COVID- 19) awal kali diumumkan oleh Presiden Republik Indonesia pada bertepatan pada 4 Maret 2020. Semenjak itu penambahan kasus terus terjadi secara bermakna di beberapa daerah di Indonesia sampai April 2020. Pandemi ini tidak hanya menyebabkan kekhawatiran publik utamanya pada gimana virus ini memberikan dampak tidak cuma pada dimensi kesehatan namun pula dimensi kemanusiaan, sosial serta ekonomi secara lebih luas. Pemerintah Indonesia merespons perihal tersebut dengan menghasilkan Keputusan Presiden( Keppres) No 7 Tahun 2020 tentang Gugus Tugas Percepatan Penindakan Virus Corona yang terletak di bawah serta bertanggung jawab kepada presiden. Pembentukan Gugus Tugas diharapkan bisa membantu Presiden sehubungan dengan terdapatnya penularan COVID- 19 di Indonesia yang membutuhkan langkah langkah kilat, pas, fokus, terpadu, serta sinergis antara departemen/ lembaga serta pemerintah wilayah. Departemen Kesehatan Republik Indonesia( Kemkes) ialah salah satu anggota Gugus Tugas yang memiliki kedudukan berarti serta memimpin dalam upaya tersebut, (Kementerian Kesehatan RI Direktorat Jenderal Derektorat Promosi Kesehatan dan Pemberdayaan Masyarakat, 2020).

Khususnya di Propinsi Jawa Timur yang ialah salah satu daerah dimana penyebaran virus Corona pula terus menunjukkan pergerakan secara ekponensial dari hari ke hari serta belum menampilkan pergerakan menurun hingga disaat ini. Pada bertepatan pada yang sama juga diinformasikan pada halaman http://infocovid19 . Jatimprov.go.id/ kalau informasi kasus positif di propinsi Jawa Timur telah mencapai 1766 dan jumlah kasus sembuh sebanyak 278 (15.74\%) dan kasus meninggal sebanyak 166 (9.40\%). Dengan menggunakan data- data yang disajikan dalam situs tersebut, hingga bisa dianalisa tentang bagaimana sebenarnya peta penyebaran virus corona ini dari waktu ke waktu(Yustanti et al., 2020).

Kasus di Kabupaten Kediri yang terkomfirmasi covid-19 pada tanggal yang diinformasikan pada situs atau laman http://covid19.kedirikab.go.id/ bahwa 
terdapat kasus kasus terkonfirmasi positif Covid-19 senin,29 Juni 2020 sebanyak 202 pada hari jumat 31 Juli 2020 kasus yang terkonfirmasi covid sebanyak 407 sehingga kenaikan kasus di bulan juni hingga juli serta pada hari rabu 5 Agustus 2020 terdapat kasus yang terkonfirmasi positif covid-19 sebanyak 486 hal tersebut adanya kenaikan kasus covid-19 di kabupaten kediri.

Pada data kasus yang terkomfirmasi covid-19 di UPTD Puskesmas Pare pada bulan Oktober terdapat sejumlah 148 kasus hal tersebut terdapat penurunan pada bulan selanjutnya di bulan November sebanyak 125 kasus dari bulan tersebut terdapat penurunan sesuai data di UPTD Puskesmas Pare pada bulan selanjutnya Desember sebanyak 135 kasus maka terdapat peningkatan kembali kasus yang terkonfirmasi covid-19 di bulan Desember.

Akibat penyebaran Covid-19 menyebabkan dampak seperti ada bidang pekerjaan yang banyak dilakukan PHK, perubahan perilaku masyarakat terutama dalam bidang kesehatan, hingga pada dampak ekonomi (Ulya, 2020). Dampak covid-19 pada dunia pendidikan sangat besar dan dirasakan oleh berbagai pihak terutama guru, kepala sekolah, peserta didik dan orang tua. Akibat penyebaran covid-19 yang tinggi di Indoensia, universitas dan perguruan tinggi lainnya ditutup tidak terkecuali sekolah dasar. Sehingga dilakukannya penutupan sekolah, maka pemerintah mengambil langkah agar proses pembelajaran tidak tertinggal dan peserta didik tetap menerima hak untuk mendapatkan ilmu. Maka dari itu keputusan pemerintah selanjutnya yaitu proses pembelajaran tetap berlangsung tapi tidak dengan tatp muka melainkan dengan online. Banyak organisasi menggunakan metode penyampaian untuk pelatihan pegawai dengan pembelajaran online (Simmons 2002 dalam Mastura \& Santaria, 2020)

Pengetahuan tentang penyakit Covid-19 merupakan hal yang sangat penting agar tidak menimbulkan peningkatan jumlah kasus penyakit Covid19. Pengetahuan pasien Covid-19 dapat diartikan sebagai hasil tahu dari pasien mengenai penyakit, memahami penyakit, cara pencegahan, pengobatan dan komplikasinya (Sari \& Atiqoh,2020). Salah satu untuk meningkatkan pengetahuan adalah melalui edukasi. Edukasi pada umumnya menggunakan metode ceramah (Arsyad,2003). Selain metode ceramah, terdapat metode penyebaran leaflet yang dapat digunakan 
untuk edukasi. Leaflet merupakan media berbentuk selembaran kertas yang diberi gambar dan tulisan (biasanya lebih banyak berisi tulisan),(Sabarudin et al., 2020).

Langkah untuk pencegahan penularan covid-19 di masyarakat yaitu melakukan secara rutin membersihkan tengan dengan sabun, gunakan hand sanitizer, menghindari menyentuh bagian wajah pada saat tangan kotor, melakukan etika batuk dan bersin yang benar, gunakan masker dan jaga jarak (minimal 1 meter). (Jaji,2020 dalam Suprayitno et al., 2020).Fenomena di lapangan hasil pengamatan peneliti banyak ditemukan masyarakat di beberapa tatanan, seperti pasar, tempat-tempat umum lainnya mereka banyak tidak melakukan pencegahan, yang paling terlihat jelas yaitu tidak memakai masker, tidak terlalau peduli dengan sosial distanching dan teramati jarang mencucui tangan.

Kompenen perilaku masyarakat dalam pencegahan penularan covid 19 secara teori meliputi: pengetahuan, sikap dan tindakan. Untuk menjadikan suatu kebiasaan itu menjadi suatu perilaku, METODE PENELITIAN

Penelitian ini menggunakan desain quasi experiment dengan rancangan one group pretest dan posttest. Intervensi yang dimulai dari pengetahuannya harus baik terhadap sesuatu yang bakal menjadi perubahan perilaku, dalam hal ini adalah pengetahuannya. Darimana masyarakat dapat pengetahuan, selain dari media elektronik dan surat kabar dan lain-lainnya adalah dari petugas kesehatan dengan menggunakan berbagai metode dan media Disinilah peneliti tertarik untuk meneliti adakah pengaruh pendidikan kesehatan dengan media leaflet terhadap pengetahuan warga dalam pencegahan covid 19 di masa pandemic, alasan memilih leaflet adalah media sederhana tapi menarik dan mudah untuk dibagikan (Jaji, 2020). Alasan tersebut sehingga peneliti ingin memberiakan intervensi dengan eduaksi online dengan menggunakan media leaflet online kepada pasien rawat jalan di UPTD Puskesmas Pare Kabupaten Kediri. Adapun tujuan penulis laporan ini untuk mengetahui peningkatan pengetahuan menggunakan media leaflet tentang pencegahan penularan covid-19.

digunakan berupa pemberian edukasi online melalui media leaflet untuk meningkatkan pengetahuan pasien rawat 
jalan di UPTD Puskesmas Pare Kabupaten

Kediri. Populasi pada penelitian ini adalah pasien rawat jalan yang terdaftar pada minggu ke 2 bulan Mei 2021 pada saat pandemi Covid-19 dengan jumlah 150 orang. Dari populasi tersebut diperoleh sampel sebanyak 20 sampel. Sampel dipilih dengan menggunakan metode purposive sampling yang memenuhi kriteria inklusi. Adapun kriteria inklusi dalam penelitian ini yaitu bersedia menjadi peserta group Whatsapp, berdomisili Pare serta bukan tenaga kesehatan. Sedangkan kriteria eksklusinya peserta yang tidak mengisi salah satu pretest atau posttest yang diberikan. Peneliti membuatkan grup whatsapp agar memudahkan kontak dengan responden. Instrumen yang digunakan selama penelitian yaitu kuesioner yang disajikan dalam google formulir dan pemberian intervensi dilakukan peneliti dengan edukasi online dengan menggunakan leaflet online di group whatsapp. Peneliti sudah melakukan observasi pertama pretest sehingga peneliti dapat mengetahui perubahan yang terjadi setelah diberikan intervensi dan kemudian dilakukan posttest. Instrumen penelitian merupakan alat untuk mengumpulkan data. Instrument adalah berbagai alat ukur yang digunakan secara sistematis untuk mengumpulkan data, seperti tes, kuesioner, dan pedoman wawancara. Terdapat dua instrument dalam penelitian dan pengembangan yaitu instrument yang digunakan untuk mengukur validasi produk yang berupa barang dan instrument yang digunakan untuk mengukur validitas produk yang bukan barang (Jatmika et al., 2019). Kuesioner yang diberikan kepada pasien rawat jalan UPTD Puskesmas Pare Kabupaten Kediri dengan menggunakan Google Form meliputi pengetahuan tentang pencegahan Covid-19 berisi 10 pertanyaan yaitu :

1. Pengertian covid-19

2. Covid-19 berapa jam bertahan hidup di luar tubuh

3. Penularan covid-19 dapat saat bicara

4. Kegunaan pemakaian masker

5. Pengertian terkait new normal

6. Cuci tangan dengan sabun waktu apa saja

7. Dimana tempat penggunaan masker

8. Berapa meter jaga jarak di luar rumah

9. Lanjut usia harus tetap jaga jarak

10. Tiap minggu apakah terjadi mobilitas 


\section{HASIL DAN PEMBAHASAN}

\section{Umur Responden}

Umur responden dalam survei tergambar dalam tabel berikut ini :

Tabel 1 Distribusi Karakteristik Responden Berdasarkan Umur

\begin{tabular}{ccc}
\hline Umur & Frekuensi & $(\boldsymbol{\%})$ \\
\hline $12-16$ tahun & 2 & 10 \\
$17-25$ tahun & 8 & 40 \\
$26-35$ tahun & 5 & 25 \\
$36-45$ tahun & 5 & 25 \\
\hline Total & $\mathbf{2 0}$ & $\mathbf{1 0 0}$ \\
\hline
\end{tabular}

Dari tabel tersebut bahwa umur responden dalam kriteria masa remaja awal 12 -16 tahun dengan sebanyak (10\%) untuk umur responden terbanyak pada kriteria masa remaja akhir 17-25 tahun dengan (40\%) serta kriteria masa dewasa awal 26-35 tahun terdapat $(25 \%)$ dan kriteria masa akhir 36-45 tahun sebanyak (25\%). Usia seseorang juga mempengaruhi terhadap daya tangkap dan pola pikir seseorang. Semakin bertambah usia akan semakin berkembang pula daya tangkap dan pola pikirnya, sehingga pengetahuan yang diperolehnya semakin baik. Pada usia 2035 tahun, individu akan lebih berperan aktif dalam masyarakat dan kehidupan sosial serta lebih banyak melakukan persiapan demi suksesnya upaya menyesuaikan diri menuju usia tua. Selain itu, mereka akan lebih banyak menggunakan banyak waktu untuk membaca. Kemampuan intelektual, pemecahan masalah dan kemampuan verbal dilaporkan hampir tidak ada penurunan pada usia ini (Suwaryo \& Yuwono,

2017)

2. Jenis Kelamin Responden

Tabel 2 Distribusi Karakteristik Responden Berdasarkan Jenis Kelamin

\begin{tabular}{ccc}
\hline Jenis Kelamin & Frekuensi & $(\boldsymbol{\%})$ \\
\hline Laki-laki & 3 & 15 \\
Perempuan & 17 & 85 \\
\hline Total & $\mathbf{2 0}$ & $\mathbf{1 0 0}$ \\
\hline
\end{tabular}

Dari tabel di atas tersebut bahwa responden dengan jenis kelamin perempuan lebih banyak dari pada responden laki-laki dengan jumlah $(85 \%)$ 


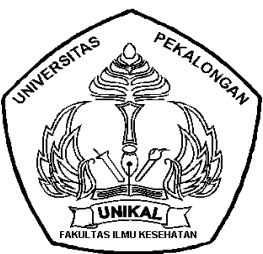

JURNAL KESEHATAN PENA MEDIKA VOL 11 (1) JUNI 2021

PENA MEDIKA

FAKULTAS ILMU KESEHATAN UNIVERSITAS PEKALONGAN

http://jurnal.unikal.ac.id/index.php/medika ISSN : 2086-843X

dengan jumlah responden laki-laki yaitu

$(15 \%)$

3. Tingkat Pendidikan Responden

Tabel 3 Distribusi Karakteristik Responden Berdasarkan Tingkat Pendidikan

\begin{tabular}{ccc}
\hline Tingkat Pendidikan & Frekuensi & $\mathbf{( \% )}$ \\
\hline SD & 2 & 10 \\
SMP & 4 & 20 \\
SMA & 10 & 50 \\
D3 & 1 & 5 \\
S1 & 2 & 10 \\
S2 & 1 & 5 \\
\hline Total & $\mathbf{2 0}$ & $\mathbf{1 0 0}$ \\
\hline
\end{tabular}

Dari tabel tersebut bahwa ditekankan bukan berarti seseorang yang responden terbanyak dengan tingkat berpendidikan berpengetahuan rendah pendidikan SMA yaitu berjumlah (50\%) pula. Hal ini mengingat pengetahuan tidak serta tingkat pendidikan tertinggi pada mutlak diperoleh dari pendidikan formal responden S2 dengan presentase (5\%). saja, akan tetapi dapat diperoleh dari Pengetahuan sendiri dipengaruhi oleh faktor pendidikan formal. Pengetahuan pendidikan non formal (Kusuma \& Putri, 2012).

sangat erat hubungannya dengan pendidikan, dimana diharapkan bahwa dnegan pendidikan yang tinggi maka orang tersebut akan semakin luas pula pengetahuannya. Akan tetapi perlu

4. Pengetahuan Respoden Tentang Pencegahan Covid-19 (Pretest)

Pengetahuan responden sebelum diberikan leaflet serta penyuluhan (pretest) dalam survei tergambar tabel berikut ini :

Tabel 4 Distribusi Pengetahuan Pasien Rawat Jalan UPTD Puskesmas Pare (Pretest)

\begin{tabular}{ccc}
\hline Pengetahuan & Frekuensi & $\mathbf{( \% )}$ \\
Baik & 3 & 15 \\
Cukup & 10 & 50 \\
Kurang & 7 & 35 \\
\hline Total & $\mathbf{2 0}$ & $\mathbf{1 0 0}$ \\
\hline
\end{tabular}




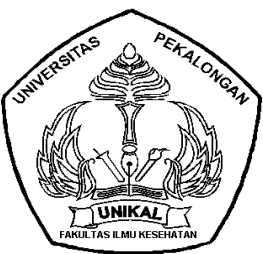

JURNAL KESEHATAN PENA MEDIKA VOL 11 (1) JUNI 2021

PENA MEDIKA

FAKULTAS ILMU KESEHATAN UNIVERSITAS PEKALONGAN

http://jurnal.unikal.ac.id/index.php/medika ISSN : 2086-843X

Dari tabel diatas dapat dilihat bahwa

dari pengetahuan sebelum dilakukan penyuluhan mengunakan media leaflet tentang pencegahan penularan covid-19, pada responden dengen kriteria baik (15\%) dengan kriteria cukup pengetahuan responden sebesar (45\%) serta untuk kriteria kurang terdapat (40\%).

\section{Pengetahuan Respoden Tentang Pencegahan Covid-19 (Posttest)}

Pengetahuan responden sesudah diberikan leaflet serta penyuluhan (posttest) dalam survei tergambar tabel berikit ini :

Tabel 5 Distribusi Pengetahuan Pasien Rawat Jalan UPTD Puskesmas Pare (Posttest)

\begin{tabular}{ccc}
\hline Pengetahuan & Frekuensi & $\mathbf{( \% )}$ \\
\hline Baik & 8 & 40 \\
Cukup & 7 & 35 \\
Kurang & 5 & 25 \\
\hline Total & $\mathbf{2 0}$ & $\mathbf{1 0 0}$ \\
\hline
\end{tabular}

Dari tabel diatas dapat dilihat bahwa dari pengetahuan sesudah dilakukan penyuluhan di rawat jalan UPTD Puskesmas Pare dengan mengunakan media leaflet tentang pencegahan penularan covid-19 pada responden diperoleh kriteria baik sebesar (40\%) serta untuk kriteria cukup terdapat sebesar $(35 \%)$, pada responden dengan kriteria kurang terdapat sebanyak(25\%).

Penyuluhan dengan metode pemberian leaflet menampilkan penjelasan pencegahan covid-19 berupa pengertian covid-19, cuci tangan pakai sabun, pemakaian masker, menjaga jarak, etika batuk berserta gejala klinis covid19 sehingga pasien rawat jalan UPTD Puskesmas Pare memudahkan menerima materi tersebut dan terjadi peningkatan pengetahuan bagaimana cara yang tepat dalam mencegah penularan covid-19.

Metode penyuluhan juga dapat dipakai pada sasaran dengan pendidikan rendah maupun tinggi, dan waktu penyuluhan dilakukan sasaran bisa berpartisipasi secara aktif dan memberikan umpan balik terhadap materi penyuluhan yang diberikan. Leaflet dipilih sebagai media karena mudah disimpan, ekonomis dan bisa berfungsi sebagai pengingat bagi sasaran. Oleh sebab itu, salah satu usaha yang dilakukan untuk meningkatkan pengetahuan adalah memberikan penyuluhan dengan pemberian leaflet (Ramadhanti et al., 2019). Selain itu 


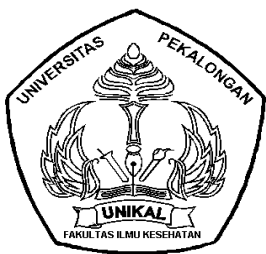

JURNAL KESEHATAN PENA MEDIKA VOL 11 (1) JUNI 2021

PENA MEDIKA

FAKULTAS ILMU KESEHATAN UNIVERSITAS PEKALONGAN

http://jurnal.unikal.ac.id/index.php/medika ISSN : 2086-843X

leaflet mempunyai keunggulan yaitu pada penyebarannya secara online, tidak mempunyai kapasitas besar untuk mengunduh sehingga tidak membutuhkan paket data yang banyak karena dalam benuk gambar. Keunggulan lainnya karena leaflet disebar secara digital maka setelah terunduh responden dapat melihatnya secara mudah dan berkali-kali. Sehingga pada pengetahuan responden mengalami peningkatan pengetahuan sebelum dan sesudah intervensi.

\section{KESIMPULAN}

Berdasarkan hasil dari survei peningkatan pengetahuan pada pasien rawat jalan di UPTD Puskesmas Pare Kabupaten Kediri sebelum dilakukan penyuluhan penerapan isi materi di media leaflet tentang pencegahan penularan covid-19 dengan $5 \mathrm{M}$ (Memakai masker, Mencuci tangan pakai sabun. Menjaga jarak, Menjauhi kerumunan, Membatasi mobilisasi dan interaksi) pada responden dengan kriteria cukup pengetahuan responden sebesar (50\%), kemudian dilakukan penyuluhan penerapan isi materi di media leaflet tentang pencegahan penularan covid-19 kriteria responden diperoleh kriteria baik sebesar (40\%) serta untuk kriteria cukup terdapat sebesar (35\%), sehingga terdapat peningkatan pengetahuan responden tentang pencegahan penularan covid-19.

\section{SARAN}

1. Mengadakan penyuluhan promosi kesehatan tentang pencegahan covid-19 di tempat UPTD Puskesmas Pare Kabupaten Kediri.

2. Meningkatkan upaya gerakan pemberdayaan masyarakat dalam pencegahan penularan covid-19

\section{DAFTAR PUSTAKA}

Jaji. 2020. Pengaruh pendidikan kesehatan dengan media leafletterhadap pengetahuan warga dalam pencegahan penularan covid 19. Proceeding Seminar Nasional Keperawatan 2020, 1 , 135-139. http://conference.unsri.ac.id/index.php/ SNK/article/view/1764

Jatmika, S. E. D., Maulana, M., Kuntoro, \& Martini, S. 2019. Buku Ajar Pengembangan Media Promosi Kesehatan.

Kementerian Kesehatan RI. 2020. Pedoman dan Pencegahan Coronavirus (COVID- 19). In Math Didactic: Jurnal Pendidikan Matematika (Vol. 4). https://doi.org/10.33654/math.v4i0.299

Kementerian Kesehatan RI Direktorat Jenderal Derektorat Promosi Kesehatan dan Pemberdayaan Masyarakat. 2020. Strategi Komunikasi Perubahan Perilaku (KPP) Dalam Pencegahan Covid-19. 
Kementerian Kesehatan RI. 2020. Pedoman Pencegahan Pengendalian Coronavirus Disease (COVID-19). In Pedoman kesiapan menghadapi COVID-19.

Kusuma, P., \& Putri, D. 2012. Pengaruh Tingkat Pendidikan, Pengetahuan, Sikap dan Terpaan Iklan Layanan Masyarakat KB Versi Shireen Sungkar dan Teuku Wisnu di TV terhadap Perilaku KB pada Wanita atau Pria dalam Usia Subur. Interaksi, 1(1), 4656.

https://doi.org/10.14710/interaksi.1.1.46 $-56$

Mastura, \& Santaria, R. 2020. Dampak Pandemi Covid-19 terhadap Proses Pengajaran bagi Guru dan Siswa Pendahuluan. Jurnal Studi Guru Dan Pembelajaran, 3(2), 289-295.

Rahmawati, I., Sudargo, T., \& Pramastri, I. 2007. Pengaruh Penyuluhan Dengan Media Audio Visual Terhadap Peningkatan Pengetahuan, Sikap Dan Perilaku Ibu Balita Gizi Kurang Dan Buruk Di Labupaten Kotawaringin Barat Provinsi Kalimatan Tengah. Gizi Klinik Indonesia , 4, 69-77.

Ramadhanti, C. A., Adespin, D. A., \& Julianti, H. P. 2019. Perbandingan Penggunaan Metode Penyuluhan Dengan Dan Tanpa Media Leaflet Terhadap Pengetahuan Dan Sikap Ibu Tentang Tumbuh Kembang Balita. Diponegoro Medical Journal (Jurnal Kedokteran Diponegoro), 8(1), 99-120.

Sabarudin, Mahmudah, R., Ruslin, Aba, L., Nggawu, L. O., Syahbudin, Nirmala, F., Saputri, A. I., \& Hasyim, M. S. 2020. Efektivitas Pemberian Edukasi secara Online melalui Media Video dan Leaflet terhadap Tingkat Pengetahuan Pencegahan Covid-19 di Kota Baubau. Jurnal Farmasi Galenika (Galenika Journal of Pharmacy) (E-Journal), 6(2), 309-318. https://doi.org/10.22487/j24428744.202 0.v6.i2.15253

Suprayitno, E., Rahmawati, S., Ragayasa, A., \& Pratama, M. Y. 2020. Pengetahuan dan Sikap Masyarakat dalam Pencegahan COVID-19. Journal Of Health Science (Jurnal Ilmu Kesehatan), 5(1), 68-73. http://www.informaticsjournals.com/ind ex.php/jhsr/article/view/8530/13618

Suwaryo, P. A. W., \& Yuwono, P. 2017. Faktor-faktor yang mempengaruhi tingkat pengetahuan masyarakat dalam mitigasi bencana alam tanah longsor. Urecol 6th, 305-314.

Ulya, H. N. 2020. Alternatif Strategi Penanganan Dampak Ekonomi Covid19 Pemerintah Daerah Jawa Timur Pada Kawasan Agropolitan. El-Barka: Journal of Islamic Economics and Business, 3(1), 80-109. sasasahttps://doi.org/10.21154/elbarka.v 3i1.2018

Word Health Organization. 2020. Anjuran mengenai penggunaan masker dalam konteks COVID-19. April.

Yustanti, W., Rahmawati, N., \& Yamasari, Y. 2020. Klastering Wilayah Kota/Kabupaten Berdasarkan Data Persebaran Covid-19 di Propinsi Jawa Timur dengan Metode K-Means. Journal Information Engineering and Educational Technology, 4(1), 1-9. 